\title{
The influence of European pollution on ozone in the Near East and northern Africa
}

\author{
B. N. Duncan ${ }^{1, *}$, J. J. West ${ }^{2}$, Y. Yoshida ${ }^{1, *}$, A. M. Fiore ${ }^{3}$, and J. R. Ziemke ${ }^{1, *}$ \\ ${ }^{1}$ Goddard Earth Sciences and Technology Center, University of Maryland, Baltimore County, Baltimore, MD, USA \\ ${ }^{2}$ Department of Environmental Sciences \& Engineering, University of North Carolina, Chapel Hill, NC, USA \\ ${ }^{3}$ Geophysical Fluid Dynamics Laboratory, National Oceanic and Atmospheric Administration, Princeton, NJ, USA \\ *also at: The Atmospheric Chemistry and Dynamics Branch, NASA Goddard Space Flight Center, Greenbelt, MD, USA
}

Received: 13 November 2007 - Published in Atmos. Chem. Phys. Discuss.: 4 February 2008

Revised: 2 April 2008 - Accepted: 16 April 2008 - Published: 25 April 2008

\begin{abstract}
We present a modeling study of the long-range transport of pollution from Europe, showing that European emissions regularly elevate surface ozone by as much as $20 \mathrm{ppbv}$ in summer in northern Africa and the Near East. European emissions cause $50-150$ additional violations per year (i.e. above those that would occur without European pollution) of the European health standard for ozone (8-h average $>120 \mu \mathrm{g} / \mathrm{m}^{3}$ or $\sim 60 \mathrm{ppbv}$ ) in northern Africa and the Near East. We estimate that European ozone pollution is responsible for 50000 premature mortalities globally each year, of which the majority occurs outside of Europe itself, including $37 \%$ (19000) in northern Africa and the Near East. Much of the pollution from Europe is exported southward at low altitudes in summer to the Mediterranean Sea, northern Africa and the Near East, regions with favorable photochemical environments for ozone production. Our results suggest that assessments of the human health benefits of reducing ozone precursor emissions in Europe should include effects outside of Europe, and that comprehensive planning to improve air quality in northern Africa and the Near East likely needs to address European emissions.
\end{abstract}

\section{Introduction}

Ozone has been associated with increased risk of premature mortality in a large number of epidemiological daily timeseries studies (Levy et al., 2001, 2005; Thurston and Ito, 2001; Anderson et al., 2004; Bell et al., 2004, 2005, 2006;

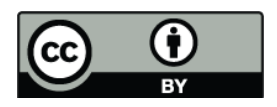

Correspondence to: B. N. Duncan (bryan.n.duncan@nasa.gov)
Gryparis et al., 2004; Ito et al., 2005). The adverse health effects of exposure to high ozone have been known for some time (Kleinfield et al., 1957; Challen et al., 1958). The highest ambient concentrations are found in areas near urban/industrial centers and biomass burning activities where short-lived maxima are often observed that can be harmful to human health (e.g. Young et al., 1964; Hallet, 1965; Stockinger, 1965). Consequently, many industrialized nations have adopted ozone control strategies with the intent to keep ambient ozone below levels considered unhealthy to humans. For example, the current European standard is $120 \mu \mathrm{g} / \mathrm{m}^{3}$ ( $\sim 60 \mathrm{ppbv}$ ) taken as an 8 -h average.

The long-range transport of ozone and its precursor compounds allows pollution from one region to impact air quality in regions thousands of kilometers downwind. Recent research has focused on the intercontinental transport of ozone and its precursors between the industrialized regions of eastern Asia, North America, and Europe (e.g. Auvray and Bey, 2005; Berntsen et al., 1999; Collins et al., 2000; Fiore et al, 2002a; Jacob et al., 1999; Jaffe et al., 1999; Prather et al, 2003; Stohl et al., 2003; Trickl et al., 2003; Wild et al., 2004). Several modeling studies have shown that pollution from one region can directly elevate the ozone in another, where the contribution of inter-continental transport is generally less than about $10 \%$ of the total ozone (e.g. Auvray and Bey, 2005). However, Li et al. (2002) attributed $20 \%$ of the violations of the European ozone standard during summer 1997 to North American sources.

European pollution has a much greater direct impact on air quality in downwind populated regions than pollution from either North America or eastern Asia as it is largely exported near the surface over land to the Arctic and Russia in winter and to northern Africa and the Middle East in summer (e.g.

Published by Copernicus Publications on behalf of the European Geosciences Union. 
Duncan and Bey, 2004, and references therein). (In contrast, pollution from North America and eastern Asia is typically exported to the Atlantic and Pacific Oceans, respectively.) Trace gas composition in the Mediterranean is particularly influenced by European pollution because of northerly flow that predominates in summer (e.g. Kallos et al., 1998; Kallos et al., 2007) and conditions favorable to the photochemical production of ozone (Lelieveld et al., 2002; Stohl et al., 2002; Roelofs et al., 2003; Henne et al., 2005). Duncan and Bey (2004) used a chemistry and transport model (CTM) to show that the long-range transport of ozone generated from European pollution caused the European standard for ozone to be exceeded regularly during the summer of 1994 over much of northern Africa (i.e. countries bordering the Mediterranean Sea) and the Near East (i.e. Israel, Lebanon, Syria, Jordan, Palestine and Iraq), regions with about 200 million inhabitants; they found that European sources contributed 5-20 ppbv ozone to these regions as a monthly mean.

The purpose of our study is to quantify the impact of European pollution on ozone in northern Africa and the Near East and to estimate its significance for air quality and human health. We use the Global Modeling Initiative's (GMI) tropospheric CTM to simulate the nonlinear photochemistry of ozone precursors and the concomitant generation of ozone in and downwind of Europe for 2001. In Sect. 2, we briefly describe the GMI CTM and the meteorological fields used to drive its transport. We present a model evaluation in Sect. 3. In Sect. 4, we use the GMI CTM to assess the impact of European pollution on ozone in northern Africa and the Near East. In Sect. 5, we estimate the number of premature mortalities associated with European ozone. A summary of conclusions is given in Sect. 6.

\section{Global Modeling Initiative's Troposphere CTM}

In this manuscript, we describe aspects of the GMI CTM and several new features that are relevant to this study. More detailed descriptions of the tropospheric chemistry and transport processes in the GMI CTM are given in Ziemke et al. (2006) and Duncan et al. (2007). We use model version 2.3.5.

We simulate conditions appropriate for 2001. The meteorological fields are from the Goddard Modeling and Assimilation Office (GMAO) GEOS-4 data assimilation system (GEOS-4-DAS) (Bloom et al., 2004). Features of the circulation, such as anticyclones, are realistically represented because of the data constraints on meteorological analyses from GEOS-4. The fields have been regridded to 42 vertical levels with a lid at $0.01 \mathrm{hPa}$. The horizontal resolution is $2^{\circ}$ latitude $\times 2.5^{\circ}$ longitude.

The tropospheric chemical mechanism includes 82 species, 223 chemical reactions, and 49 photolysis reactions. It includes a detailed description of $\mathrm{O}_{3}-\mathrm{NO}_{\mathrm{x}}-$ hydrocarbon chemistry, updated with recent experimental data (e.g. Sander et al., 2006). The GMI CTM transports 34 of the 82 species in the chemical mechanism. The chemical mass balance equations are integrated using the SMVGEAR II algorithm (Jacobson, 1995). Photolysis frequencies are computed using the Fast-JX radiative transfer algorithm (M. Prather, personal communication, 2005). The algorithm treats both Rayleigh scattering as well as Mie scattering by clouds and aerosol. The model simulates the radiative and heterogeneous chemical effects of sulfate, dust, sea-salt, organic carbon and black carbon aerosol on tropospheric photochemistry. Monthly-averaged aerosol surface area distributions were obtained from the Goddard Chemistry Aerosol Radiation and Transport (GOCART) model for 2001 (Chin et al., 2002). The aerosol fields were coupled to the GMI CTM as described by Martin et al. (2003).

The global, base fossil fuel emission inventory is the EDGAR inventory $\left(\mathrm{NO}_{\mathrm{x}}, \mathrm{CO}\right)$ for 2000 (Olivier et al., 2001) and non-methane hydrocarbons (NMHC) from Piccot et al. (1992). The base inventory is replaced by regional inventories from the European Monitoring and Evaluation Program (EMEP) database inventory for Europe (http://webdab.emep.int; Vestreng et al., 2005), Environmental Protection Agency (EPA) 1999 National Emission Inventory (http://www.epa.gov/ttn/chief/net/1999inventory. html) for the United States, Big Bend Regional Aerosol and Visibility Observational (BRAVO) Study (Kuhns et al., 2003) for Mexico, Streets et al. (2003) for eastern Asia, except China, and Streets et al. (2006) for China. The annual anthropogenic emissions from Europe are $\sim 6 \mathrm{Tg} \mathrm{N}$ of $\mathrm{NO}_{\mathrm{x}}, 78 \mathrm{Tg} \mathrm{CO}$, and $4 \mathrm{Tg} \mathrm{C}$ of NMHC. We define the European region with two boxes: i. $10^{\circ} \mathrm{W}-25^{\circ} \mathrm{E}$ and $>38^{\circ} \mathrm{N}$, and ii. $10^{\circ} \mathrm{W}-60^{\circ} \mathrm{E}$ and $>44^{\circ} \mathrm{N}$. This region includes all of Eastern Europe, several nations in the Former Soviet Union (e.g. Ukraine), and the most populated regions of western Russia. Biogenic emissions of isoprene, monoterpenes, methanol, and acetone are simulated as described in Duncan et al. (2007). Isoprene and monoterpene emissions are based on a modified version of the inventory of Guenther et al. (1995).

The emissions of $\mathrm{NO}_{\mathrm{x}}, \mathrm{NMHCs}$, and $\mathrm{CO}$ from international shipping are included in this study, as high-traffic shipping lanes are found near Europe in the North Atlantic Ocean and Mediterranean Sea. However, the impact of these emissions on tropospheric chemistry is uncertain. Chen et al. (2005) reported that $\mathrm{NO}_{\mathrm{x}}$ destruction in ship plumes is high and that nitric acid loss is high based on observations during the ITCT 2002 field campaign. Several studies have shown that CTMs that do not account for rapid in-plume destruction of $\mathrm{NO}_{\mathrm{x}}$ over-predict the hydroxyl radical and ozone (Kasibhatla et al., 2000; Davis et al., 2001; Song et al., 2003; von Glasow et al., 2003); this problem is especially egregious in low- $\mathrm{NO}_{\mathrm{x}}$ environments where ozone production efficiency is high due to its nonlinear dependence on $\mathrm{NO}_{\mathrm{x}}$ ( $\mathrm{Liu}$ et al., 1987; Lin et al., 1988). To correct this overproduction of ozone, we "pre-process" shipping $\mathrm{NO}_{\mathrm{x}}$ in model boxes 
containing open sea only, which contain one-third of total shipping emissions (3.1 Tg N/year in the EDGAR inventory), before emitting its oxidation products (ozone and nitric acid). We do not pre-process shipping emissions in model boxes containing land (e.g. ports), which we assume are high- $\mathrm{NO}_{\mathrm{x}}$ environments.

In-plume processes (e.g. particle scavenging) are highly uncertain, so our calculated ozone $\left(P_{\text {ozone }}(\mathrm{molec} / \mathrm{s}) ;\right.$ Eq. 1$)$ and nitric acid ( $P_{\text {Nitric Acid }}(\mathrm{molec} / \mathrm{s})$; Eq. 2$)$ production rates are observationally-based approximations:

$P_{\text {ozone }}=E_{\mathrm{NOx}} \times 10 \times\left(J_{\mathrm{NO} 2} / 0.0095\right)^{2}$

$P_{\text {Nitric Acid }}=E_{\text {NOx }}$

where $J_{\mathrm{NO} 2}\left(\mathrm{~s}^{-1}\right)$ is the photolysis rate of $\mathrm{NO}_{2}$ and $\mathrm{E}_{\mathrm{NOx}}$ $(\mathrm{molec} / \mathrm{s})$ is the emission rate of $\mathrm{NO}_{\mathrm{x}}$. The factor, $0.0095 \mathrm{~s}^{-1}$, is the average $J_{\mathrm{NO} 2}$ value at noon and the factor, 10 , is the ozone production efficiency (the number of molecules ozone produced per molecule $\mathrm{NO}_{\mathrm{x}}$ consumed) during the ITCT 2002 field campaign (Chen et al., 2005; G. Chen, personal communication, 2006). If $J_{\mathrm{NO} 2}$ is greater than $0.0095 \mathrm{~s}^{-1}$, we set it equal to $0.0095 \mathrm{~s}^{-1}$. The factor, $J_{\mathrm{NO} 2} / 0.0095$, is squared to limit ozone production at high latitudes in winter. We approximate $P_{\text {ozone }}$ between $\pm 60^{\circ}$ latitude as ice reflectance enhances $J_{\mathrm{NO} 2}$ at latitudes greater than $\pm 60^{\circ}$; the shipping $\mathrm{NO}_{\mathrm{x}}$ is emitted as $\mathrm{HNO}_{3}$ at latitudes greater than $\pm 60^{\circ}$. Chen et al. (2005) reported in-plume nitric acid concentrations six times lower than their box model. We do not reduce $P_{\text {Nitric Acid }}$ by six simply for the conservation of mass of nitrogen; most nitric acid will deposit anyway. Our approximation gives an annual production of ozone from open sea shipping $\mathrm{NO}_{\mathrm{x}}$ that equals $\sim 0.2 \%$ of the total tropospheric production.

We find that in summer, shipping emissions contribute $0.5-3$ ppbv to surface ozone in the major shipping lanes, except 1-7.5 ppbv in the North Atlantic, upwind of Europe. Over land, the contribution is $\sim 1 \mathrm{ppbv}$ in extreme Western Europe and generally $<0.5 \mathrm{ppbv}$ in the rest of Europe. The contribution is up to $2 \mathrm{ppbv}$ in the Mediterranean Sea and $<0.5 \mathrm{ppbv}$ in northern Africa and the Near East. In spring and fall, the contribution is $1-3$ ppbv over the North Atlantic and $<0.5 \mathrm{ppbv}$ over Europe and countries bordering the Mediterranean Sea. In winter, the contribution is far less $(<0.5 \mathrm{ppbv})$ over the North Atlantic and Mediterranean Sea. Eyring et al. (2007) reported a multi-modeled ensemble mean of 2-13 ppbv surface ozone due to shipping emissions over the North Atlantic in July, which is almost twice that as in our study; the models that participated in the study, including the GMI CTM, directly emitted shipping $\mathrm{NO}_{\mathrm{x}}$ as $\mathrm{NO}_{\mathrm{x}}$.

We use the Synoz (synthetic ozone) method of McLinden et al. (2000) to simulate the stratosphere to troposphere flux of $\mathrm{O}_{3}$ with a prescribed global mean cross-tropopause $\mathrm{O}_{3}$ flux, $550 \mathrm{Tg} / \mathrm{y}$ as recommended by Olsen et al. (2001). The tropopause height is diagnosed in the model using the criterion of Synoz equal to $150 \mathrm{ppbv}$. Above the tropopause, we remove relatively long-lived species (e.g. $\mathrm{CO}, \mathrm{C}_{2} \mathrm{H}_{6}$, etc.) assuming a 100-day lifetime. Using a similar methodology as the Synoz method, we simulate the cross-tropopause flux of a synthetic nitrogen species using the Nodoz method developed by Peter Connell (Lawrence Livermore National Labs, personal communication). The annual downward flux across the tropopause is thought to be about $0.5 \mathrm{Tg} \mathrm{N} / \mathrm{y}$ as reactive nitrogen $\left(\mathrm{NO}_{\mathrm{y}}\right)$. Assuming this flux and a $\mathrm{NO}_{\mathrm{x}} / \mathrm{NO}_{y}$ ratio of 0.2 near the tropopause in the lower stratosphere, the annual $\mathrm{NO}_{\mathrm{y}}$ flux as $\mathrm{NO}_{\mathrm{x}}$ is $0.1 \mathrm{Tg} \mathrm{N} / \mathrm{y}$ and as $\mathrm{HNO}_{3}$ is $0.4 \mathrm{Tg} \mathrm{N} / \mathrm{y}$.

\section{Model evaluation}

Evaluations of the GMI CTM can be found in several papers, including Schoeberl et al. (2006), Ziemke et al. (2006), Duncan et al. (2007), and Strahan et al. (2007). In Sect. 3.1, we evaluate the model's ability to simulate surface ozone over Europe for 2001 using observations from the EMEP network (www.nilu.no/projects/CCC/onlinedata/ ozone/index.html). Unfortunately, there is a paucity of surface observations in northern Africa and the Near East; we discuss the potential use of the tropospheric column ozone (TCO) data product from the Aura OMI and MLS instruments (Ziemke et al., 2006) to evaluate the spatial coverage and magnitude of model ozone in these regions. The ability of the model to reproduce observations reasonably well, as we show here, lends confidence in its use as a tool to study the impact of European pollution on air quality in northern Africa and the Near East.

\subsection{Surface ozone stations}

There are 67 EMEP measurement stations with data for the summer 2001. The stations are concentrated in northern and central Europe; there are few stations in southeastern Europe. We present statistical information in this section, using the following quantitative measures of model performance: $R$ is the linear correlation coefficient between model and observations and the bias is the mean of the difference between the model and observed ozone divided by the observed ozone. For our evaluation, we choose model ozone from the gridbox in which each EMEP station lies.

Figure 1 shows a comparison of the model surface ozone as monthly means (1300-1700 local time) for 2001 for a subset of EMEP observations; we chose these stations for their geographical coverage of the continent, as well as for their representativeness of a range of altitudes. The model simulates the seasonal variation of ozone at most stations quite well, including the maximum ozone observed at higher latitude stations (e.g. NO15 in Scandinavia) in spring and the maximum at most other stations in summer, when photochemical production is high. The average correlation $\left(R^{2}\right)$ is 0.90 (median=0.93) for the 67 stations, with all but 4 stations having correlations greater than 0.70 . The average annual 

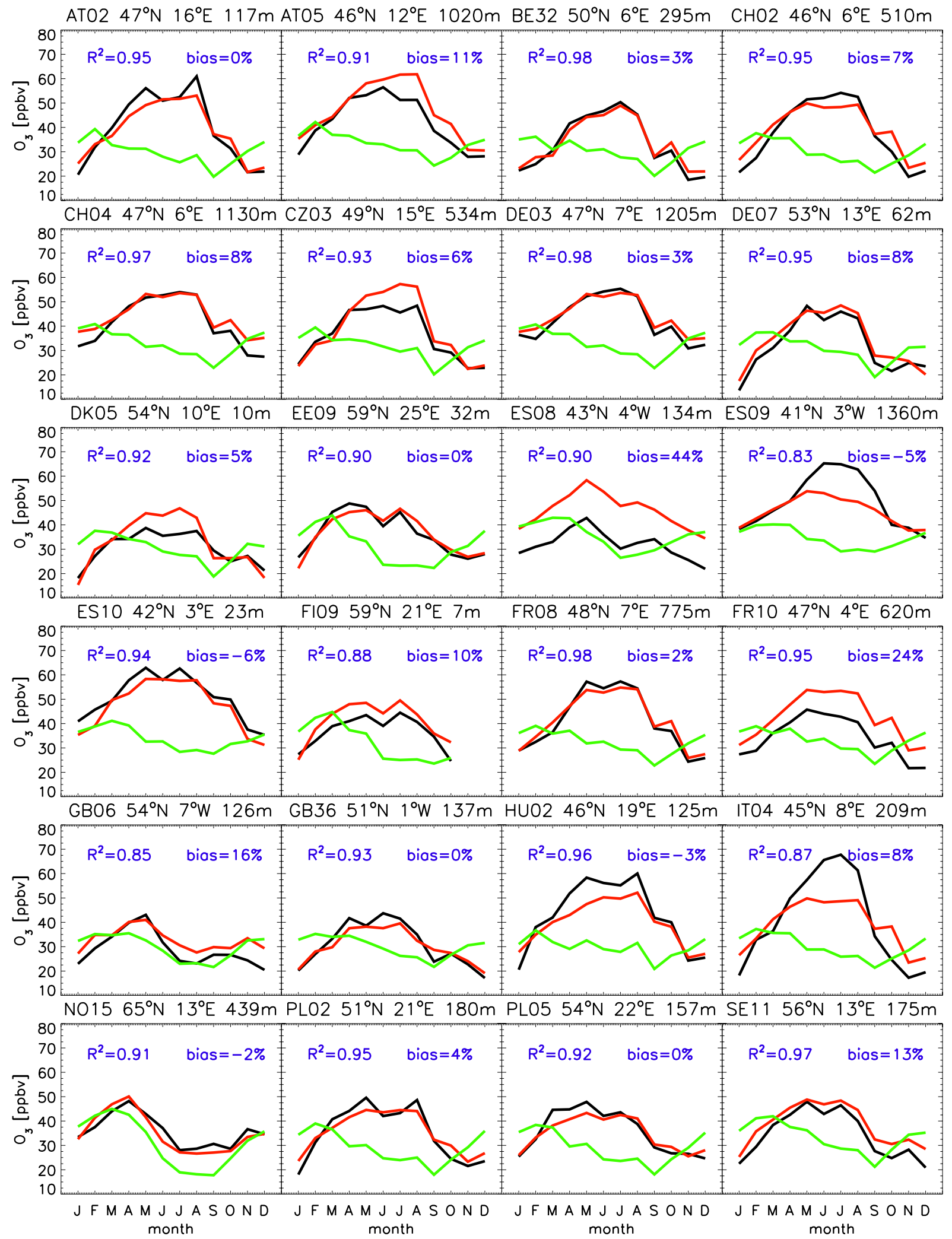

Fig. 1. Monthly-average ozone (13:00-17:00 LT; ppbv) at selected EMEP stations for 2001 for RUN1 (i.e. the base simulation; red), RUN2 (i.e. the base simulation, except without European pollutant emissions; green), and the observations (black). 
Table 1. Statistical Comparison of the Model's Daily Maximum 8-h Averages with those of EMEP Ozone Observations ${ }^{\mathrm{a}}$ for June, July and August 2001.

\begin{tabular}{|c|c|c|c|c|c|c|c|}
\hline \multirow{2}{*}{$\begin{array}{c}\text { Station } \\
\text { ID }\end{array}$} & \multirow{2}{*}{$\begin{array}{l}\text { Lat } \\
\text { deg }\end{array}$} & \multirow{2}{*}{$\begin{array}{l}\text { Lon } \\
\text { deg }\end{array}$} & \multirow{2}{*}{$\begin{array}{c}\text { Alt } \\
\mathrm{m}\end{array}$} & \multirow[t]{2}{*}{$\Delta^{\mathrm{b} \%}$} & \multirow[t]{2}{*}{$R^{2 \mathrm{c}}$} & \multicolumn{2}{|c|}{ Violations $^{\mathrm{d}}$} \\
\hline & & & & & & Obs & Mod \\
\hline AT02 & 47.8 & 16.8 & 117 & 1.9 & 0.42 & 27 & 10 \\
\hline AT04 & 47.7 & 13.2 & 851 & 11.0 & 0.45 & 27 & 39 \\
\hline AT05 & 46.7 & 13.0 & 1020 & 13.5 & 0.18 & 23 & 41 \\
\hline BE01 & 49.9 & 5.2 & 430 & 13.5 & 0.74 & 17 & 25 \\
\hline BE32 & 50.6 & 6.0 & 295 & -1.6 & 0.77 & 20 & 14 \\
\hline BE35 & 50.5 & 5.0 & 160 & 2.9 & 0.75 & 22 & 14 \\
\hline $\mathrm{CH} 02$ & 46.8 & 7.0 & 510 & -3.7 & 0.64 & 22 & 8 \\
\hline $\mathrm{CH} 03$ & 47.5 & 8.9 & 540 & -1.0 & 0.56 & 28 & 13 \\
\hline CH04 & 47.1 & 7.0 & 1130 & -4.6 & 0.74 & 37 & 23 \\
\hline CZ01 & 49.7 & 16.0 & 737 & 18.6 & 0.60 & 19 & 25 \\
\hline CZ03 & 49.6 & 15.1 & 534 & 20.7 & 0.66 & 16 & 26 \\
\hline DE01 & 54.9 & 8.3 & 12 & 8.8 & 0.73 & 10 & 16 \\
\hline DE02 & 52.8 & 10.8 & 74 & -0.3 & 0.81 & 14 & 10 \\
\hline DE03 & 47.9 & 7.9 & 1205 & -4.8 & 0.78 & 35 & 22 \\
\hline DE04 & 49.8 & 7.1 & 480 & 9.5 & 0.72 & 25 & 25 \\
\hline DE05 & 48.8 & 13.2 & 1016 & 10.6 & 0.45 & 34 & 43 \\
\hline DE07 & 53.2 & 13.0 & 62 & 13.1 & 0.45 & 3 & 9 \\
\hline DE08 & 50.7 & 10.8 & 937 & 1.0 & 0.74 & 29 & 29 \\
\hline DE09 & 54.4 & 12.7 & 1 & 12.7 & 0.60 & 2 & 9 \\
\hline DK05 & 54.7 & 10.7 & 10 & 17.4 & 0.53 & 2 & 12 \\
\hline EE09 & 59.5 & 25.9 & 32 & 10.2 & 0.29 & 0 & 1 \\
\hline EE11 & 58.4 & 21.8 & 6 & 12.2 & 0.43 & 2 & 5 \\
\hline ES07 & 37.2 & -3.5 & 1265 & 1.9 & 0.40 & 24 & 11 \\
\hline ES08 & 43.4 & -4.9 & 134 & 55.9 & 0.30 & 0 & 23 \\
\hline ES09 & 41.3 & -3.1 & 1360 & -18.4 & 0.56 & 54 & 7 \\
\hline ES10 & 42.3 & 3.3 & 23 & -2.8 & 0.51 & 44 & 39 \\
\hline ES11 & 38.5 & -6.9 & 393 & 37.0 & 0.63 & 2 & 15 \\
\hline ES12 & 39.1 & -1.1 & 885 & 3.8 & 0.46 & 28 & 39 \\
\hline ES13 & 41.3 & -5.9 & 985 & -7.6 & 0.56 & 27 & 9 \\
\hline ES14 & 41.4 & 0.7 & 470 & -1.6 & 0.46 & 18 & 4 \\
\hline ES15 & 39.5 & -4.4 & 1241 & -12.5 & 0.64 & 47 & 11 \\
\hline ES16 & 43.2 & -7.7 & 506 & 1.8 & 0.64 & 9 & 8 \\
\hline FI09 & 59.8 & 21.4 & 7 & 9.8 & 0.72 & 0 & 2 \\
\hline FI37 & 62.6 & 24.2 & 180 & 1.1 & 0.37 & 0 & 0 \\
\hline FR08 & 48.5 & 7.1 & 775 & -7.2 & 0.81 & 38 & 22 \\
\hline FR09 & 49.9 & 4.6 & 390 & 11.1 & 0.78 & 16 & 27 \\
\hline FR10 & 47.3 & 4.1 & 620 & 28.7 & 0.73 & 7 & 20 \\
\hline FR12 & 43.0 & -1.1 & 1300 & -6.5 & 0.68 & 30 & 2 \\
\hline FR13 & 43.4 & 0.1 & 236 & 20.2 & 0.61 & 7 & 3 \\
\hline FR14 & 47.2 & 6.5 & 746 & 24.7 & 0.59 & 14 & 22 \\
\hline GB02 & 55.3 & -3.2 & 243 & 37.1 & 0.59 & 0 & 6 \\
\hline GB06 & 54.4 & -7.9 & 126 & 21.8 & 0.35 & 0 & 0 \\
\hline GB13 & 50.6 & -3.7 & 119 & 32.3 & 0.47 & 4 & 14 \\
\hline GB14 & 54.3 & -0.8 & 267 & 21.9 & 0.60 & 4 & 10 \\
\hline GB36 & 51.6 & -1.3 & 137 & -1.5 & 0.71 & 3 & 4 \\
\hline GB38 & 50.8 & 0.2 & 120 & 14.5 & 0.61 & 11 & 18 \\
\hline GB43 & 51.2 & -4.7 & 160 & 22.5 & 0.65 & 1 & 10 \\
\hline GB45 & 52.3 & -0.3 & 5 & -3.1 & 0.80 & 10 & 6 \\
\hline HU02 & 47.0 & 19.6 & 125 & 0.4 & 0.69 & 31 & 7 \\
\hline IT01 & 42.1 & 12.6 & 48 & 1.9 & 0.59 & 64 & 61 \\
\hline
\end{tabular}

Table 1. Continued.

\begin{tabular}{cccccccc}
\hline Station & Lat & Lon & Alt & $\Delta^{\mathrm{b}} \%$ & $R^{2 \mathrm{c}}$ & \multicolumn{2}{c}{ Violations } \\
ID & deg & deg & $\mathrm{m}$ & & & Obs & Mod \\
\hline IT04 & 45.8 & 8.6 & 209 & -13.2 & 0.40 & 39 & 8 \\
LT15 & 55.4 & 21.1 & 5 & 23.6 & 0.50 & 1 & 24 \\
NL09 & 53.3 & 6.3 & 1 & 41.1 & 0.57 & 2 & 16 \\
NL10 & 51.5 & 5.9 & 28 & 3.5 & 0.65 & 13 & 10 \\
NO01 & 58.4 & 8.3 & 190 & 37.5 & 0.20 & 0 & 9 \\
NO15 & 65.8 & 13.9 & 439 & -8.7 & 0.48 & 0 & 0 \\
NO39 & 62.8 & 8.9 & 210 & 20.2 & 0.08 & 0 & 0 \\
NO41 & 61.3 & 11.8 & 440 & -2.7 & 0.31 & 0 & 0 \\
PL02 & 51.8 & 22.0 & 180 & 5.4 & 0.18 & 6 & 0 \\
PL03 & 50.7 & 15.7 & 1603 & 10.8 & 0.50 & 25 & 28 \\
PL04 & 54.8 & 17.5 & 2 & 6.1 & 0.41 & 3 & 4 \\
PL05 & 54.2 & 22.1 & 157 & 5.7 & 0.25 & 1 & 0 \\
RU18 & 54.9 & 37.8 & 150 & 21.3 & 0.23 & 0 & 0 \\
SE02 & 57.4 & 11.9 & 10 & 3.5 & 0.50 & 4 & 5 \\
SE11 & 56.0 & 13.2 & 175 & 11.7 & 0.51 & 3 & 12 \\
SE12 & 58.8 & 17.4 & 20 & 20.7 & 0.75 & 1 & 7 \\
SI08 & 45.6 & 14.9 & 520 & 25.7 & 0.29 & 35 & 59 \\
AVG & & & & 9.9 & 0.54 & 15.5 & 14.9 \\
MED & & & & 9.5 & 0.57 & 11.0 & 10.0 \\
\hline
\end{tabular}

a Station descriptions are at www.nilu.no/projects/CCC/ sitedescriptions/index.html.

$\mathrm{b}$ The bias (\%) is the mean of (model-observed)/observation for the time period; the number of daily observations coincident with the model output are between 86 and 92 .

c $R$ is the linear correlation coefficient between the model and observations.

d Number of violations of the 8-h European ozone standard ( $\sim 60$ ppbv).

e Average of 67 stations.

${ }^{f}$ Median of 67 stations.

mean model bias is $11 \%$ (median=9.4\%) with a range from $-6.9 \%$ to $44 \%$; the range of biases is higher in summer as discussed below. In general, the largest biases occur near coastlines and mountainous regions. This result is expected as ozone in these regions is influenced by sub-grid processes, such as sea breezes and complex transport in and around mountains. About two-thirds of the stations lie in model boxes containing, to some degree, coasts and/or mountains.

We present averages for the afternoon, when high ozone events predominantly occur, because ozone in the first model level is more comparable to surface observations during the day than at night as the boundary layer is well-mixed (Jacob et al., 1993a and references therein). There are two important nighttime sub-grid processes that are not resolved in most CTMs, including the GMI CTM. First, the titration of ozone by NO is common in the shallow nocturnal boundary layer in polluted regions. Due to spatial averaging over the model grid, nighttime ozone tends to be biased high in 
our simulation. However, titration is not a permanent loss for ozone since $\mathrm{NO}_{2}$, the product of the reaction, will most likely photolyze after sunrise leading to the production of ozone. Second, the model's first layer does not capture the observed vertical gradient at night that results from the deposition of ozone at the surface.

A comparison of maximum 8-h average data for each day for a subset of the stations is shown in Fig. 2 for June-August 2001. The CTM simulates the day-to-day variability in summer quite well at most stations, including the duration and frequency of episodic high-ozone events. The average correlation $\left(R^{2}\right)$ is 0.54 (median $=0.57$ ) for the 67 stations (Table 1). Similarly to the monthly average ozone in Fig. 1, the largest biases typically occur at stations near coastlines (where the model tends to overestimate) and mountainous regions (where the model tends to underestimate the observations).

The model ozone is higher than observations at 48 of the 67 stations during summer, when photochemical production is the dominant source of ozone; the average bias for all stations is $9.9 \%$ (median $=9.5 \%$ ) for June-August with a range of $-18 \%$ to $56 \%$ (Table 1). A high bias during summer is common in CTMs in polluted regions (e.g. Auvray and Bey, 2005; Murazaki and Hess, 2006) and may be related to the spatial averaging of emissions (e.g. the nonlinear dependence of ozone production on $\mathrm{NO}_{\mathrm{x}}$ (Liu et al., 1987; Lin et al., 1988)). The bias typically decreases in CTMs with finer resolution grids or sub-grid urban chemistry parameterizations (e.g. Sillman et al., 1990; Jacob et al., 1993b; Liang and Jacobson, 2000; Park et al., 2004; Wild and Prather, 2006). Despite this, Fiore et al. (2003) showed that CTMs with coarse resolutions are able to adequately capture synoptic-scale processes that influence surface ozone, which our CTM does as shown in Fig. 2. Another possible reason for the high bias is the uncertainty associated with biogenic emissions over Europe (e.g. Fiore et al., 2005; Guenther et al., 2006); this uncertainty is particularly relevant since the number of ozone molecules produced per carbon oxidized is high for isoprene relative to most anthropogenic NMHCs (Chameides et al., 1992). There are $25 \mathrm{Tg} \mathrm{C} / \mathrm{y}$ of isoprene emitted in the European region, far exceeding the $4 \mathrm{Tg} \mathrm{C} / \mathrm{y}$ from anthropogenic sources.

The model simulates reasonably well the number of violations of the health standard for ozone at most stations, despite the model's general high bias (Table 1). Averaging over the 67 stations, the model and observations show about 15 violations in June, July and August. However, the model does not perform well at a number of high altitude and coastal/near coastal stations. The largest under-predictions of violations typically occur at high altitude stations (e.g. ES09, ES15, FR12), where the stations are in the free troposphere while the average model box heights put the stations in the boundary layer. Ozone at high-altitude stations in Europe tends to be higher on average than ozone at stations below 1000$1200 \mathrm{~m}$ due to titration and deposition; however, variability is higher at stations below $1000-1200 \mathrm{~m}$, especially in polluted regions in summer (e.g. Reiter et al., 1987; Wunderli and Gehrig, 1990; Chevalier et al., 2007). The largest overpredictions tend to occur at stations near coasts (e.g. ES08, LT15, NL09).

In summary, our model evaluation with EMEP observations shows that the model's daily maximum 8-h average surface ozone is generally $10 \%$ higher in summer than observations over Europe, though 1) the model captures the temporal and spatial variation of surface ozone quite well and 2) the number of violations of the health standard for ozone in the model is biased a little low $(\sim 4 \%)$. We cannot extrapolate the high bias of surface ozone in Europe to northern Africa and the Near East as 1) the photochemical environment in these regions is different than in Europe (e.g. lower local emissions, more sunlight) and 2) there is no evidence that the model's surface ozone in summer in the Northern Hemisphere midlatitudes is systematically biased high as compared to ozonesondes (J. Logan, Harvard University, personal communication).

\subsection{Tropospheric column ozone}

We show in this section that the TCO product of Ziemke et al. (2006), which is derived from observations from space, is of limited use for air quality applications, including in observation-sparse regions such as northern Africa and the Near East. Ziemke et al. (2006) compared TCO observations with those of the GMI CTM. (However, different emission sources and meteorological fields were used than in the simulations presented in this manuscript.) They found that the two agreed well both spatially and seasonally, including for the South Atlantic maximum, to within $\sim 10 \%$. The simulated ozone was typically higher from $30-40^{\circ}$ latitude in both hemispheres, particularly the Northern Hemisphere $(+20 \%)$, and too low over the Warm Pool $(-20 \%)$ in all seasons. Ozonesonde data support the finding that the simulated TCO from $30-40^{\circ} \mathrm{N}$ was too high. In general, we find similar results for the simulation of the GMI CTM presented here as shown in Fig. 3a, b for July; we use the same tropopause pressures as Ziemke et al. (2006).

The TCO product is not likely to be useful directly for air quality applications, such as in the present study, based on the following considerations. First, the sensitivity of the OMI instrument to the boundary layer is relatively lower than it is to the mid and upper troposphere (Bhartia et al., 1996). Second, the boundary layer $(<3 \mathrm{~km})$ contributes $<30 \%$ to the TCO as estimated in our model simulation for the study region (Fig. 3c), with a weak seasonal variation. Therefore, it will be difficult to isolate the variability in the portion of the column in the boundary layer from that portion in the rest of the troposphere, especially given the large dayto-day variability in the TCO in the extra-tropics associated with stratosphere-troposphere exchange, photochemical production, and tropopause height variations (de Laat et al., 

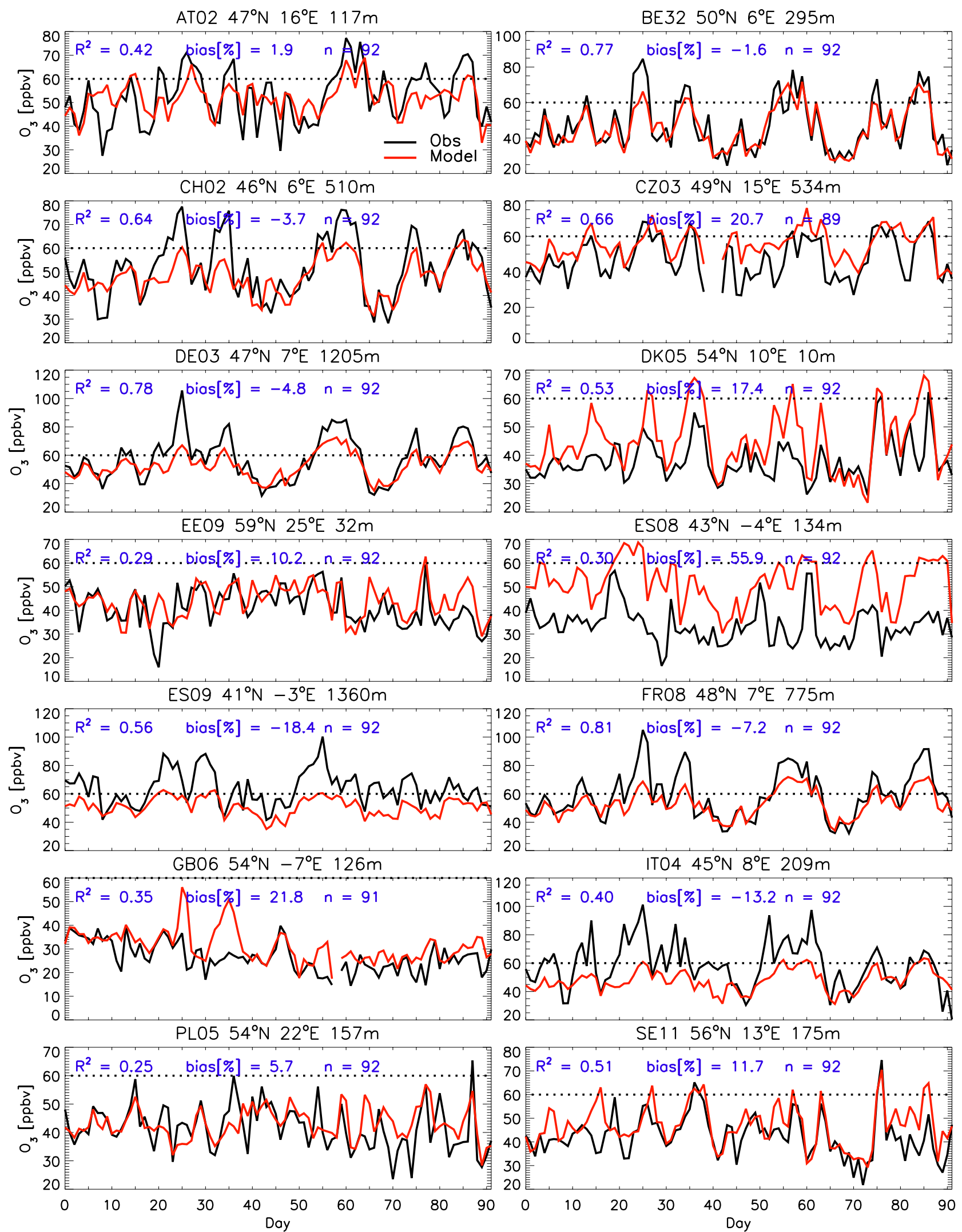

Fig. 2. Observed (black) and modeled (red) maximum 8-h average ozone (ppbv) for June, July, and August 2001 at selected EMEP stations. 


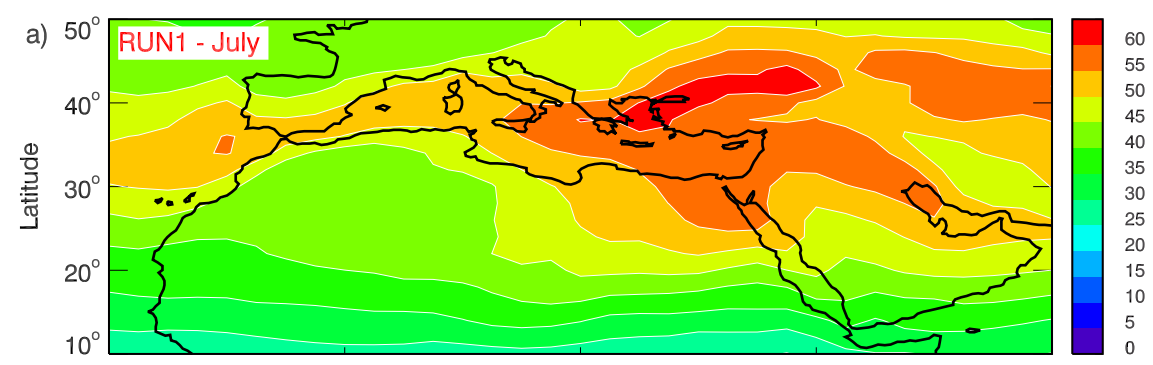

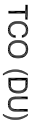
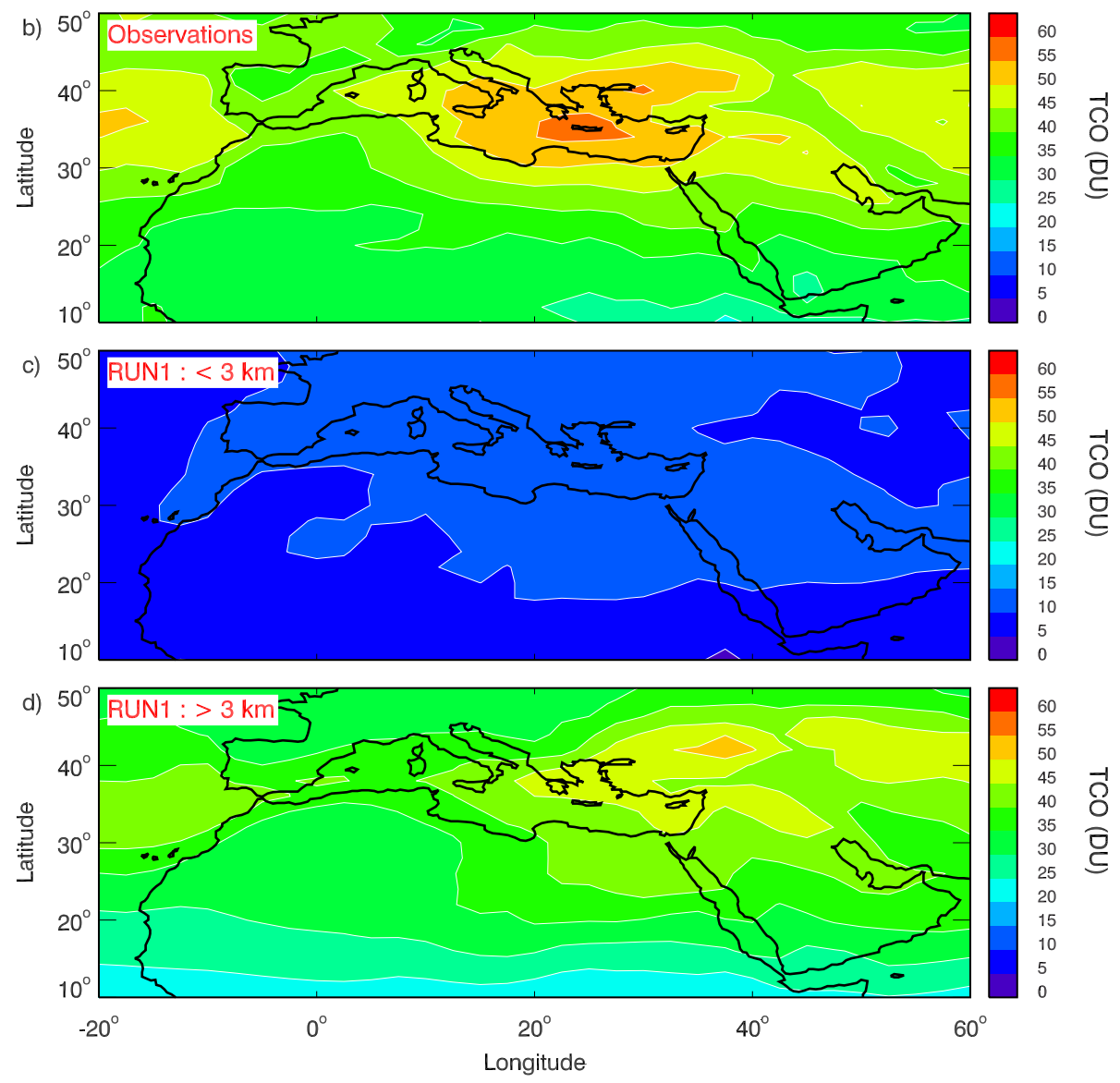

Fig. 3. The (a) model (2001) and (b) observed (2005) TCO (Dobson Units (DU) $=0.01 \mathrm{~mm}$ thickness at standard temperature and pressure) for July. (c) The portion of the model TCO (DU) $<3 \mathrm{~km}$ and (d) the portion $>3 \mathrm{~km}$.

2005). In general, we find that the mid and upper troposphere ozone effectively obscures the weaker boundary layer signal (Fig. 3d). On a global scale, the contribution of the boundary layer is generally lower in the Southern Hemisphere than the Northern Hemisphere and the contribution is higher in winter than summer in the Northern Hemisphere. The contribution in areas where photochemical production is important in the boundary layer (e.g. biomass burning regions and industrial regions in summer) is higher than in non-polluted regions, but still typically $<30 \%$.

\section{Impact of European emissions on surface ozone pol- lution}

In this section, we show that European pollution regularly impacts air quality in northern Africa and the Near East. We present the results of two GMI CTM simulations, the base simulation for 2001 (RUN1) and a second simulation (RUN2) without European anthropogenic emissions (i.e. CO, $\mathrm{NO}_{\mathrm{x}}, \mathrm{NMHC}$, and aerosols). In RUN2, all anthropogenic sources (i.e. industry and transportation, including ships and aircraft) are removed, but the natural and biogenic emissions are not. We refer to the difference in ozone concentrations between the two runs as the perturbation caused by European emissions. 
a)
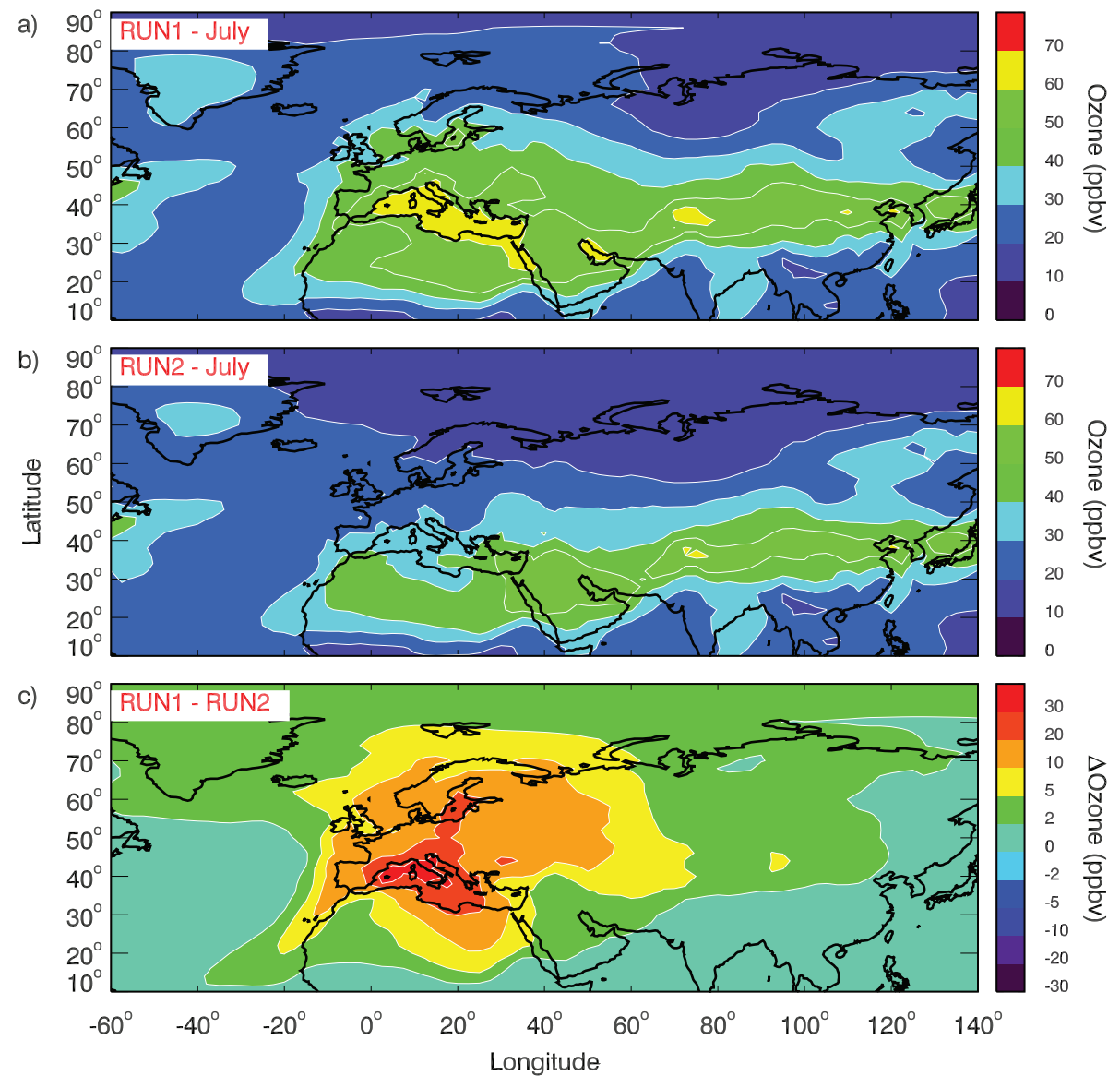

Fig. 4. Monthly-average surface ozone (1-24h; ppbv) for July 2001 for the (a) RUN1 (i.e. base simulation), (b) RUN2 (i.e. the base simulation without European emissions), and (c) difference between RUN1 and RUN2.

Figure 1 shows monthly-averaged surface ozone for both RUN1 and RUN2. Clearly, European pollution has a large impact on ozone at the European stations from spring through fall when ozone is often twice as high, especially in southern Europe (e.g. CH04, ES10). Interestingly, the summer maximum seen in RUN1 is replaced by a late winter/early spring maximum in RUN2 at all stations; a spring maximum has been observed at many remote Northern Hemisphere stations, though the origin of the phenomenon is not well understood (e.g. Monks, 2000).

Figure $4 a-b$ shows the July mean surface ozone for RUN1 and RUN2, including the difference between the two simulations (Fig. 4c). The average surface ozone in RUN1 is about 60-70 ppbv in the Mediterranean basin, similar to the range of observations collected from $0-2 \mathrm{~km}$ during the Mediterranean Intensive Oxidant Study (MINOS) field campaign in August 2001 (Lelieveld et al., 2002; Traub et al., 2003). The maximum perturbation (20-30 ppbv) occurs over the Mediterranean Basin and adjacent regions, including northern Africa (Fig. 4c). The impact of European emissions on surface ozone is widespread, enhancing ozone levels from the North Atlantic to East Asia and from the Arctic Circle to tropical Africa.
Ozone over northern Africa and the Near East is 5-20 ppbv higher on average due to European emissions of ozone precursors. The long-range transport of European pollution occurs at low altitudes $(<5 \mathrm{~km})$ from Europe south across the Mediterranean Sea. This can be seen in Fig. 5, which shows a vertical cross-section $\left(15^{\circ} \mathrm{E}\right)$ in July of the difference in the model ozone between RUN1 and RUN2. The export of the plume from Europe at low altitudes complicates its detection from space as discussed in Sect. 3.2.

Figure 6 shows the monthly-averaged ozone perturbation near the surface for January, April, and October 2001. In contrast to summer (Fig. 4c), the perturbation in winter is negative over all of Europe, with the greatest negative perturbations $(<-10 \mathrm{ppbv})$ co-located with high $\mathrm{NO}_{\mathrm{x}}$ emissions over northwest Europe; this occurs because the titration of ozone by NO is more important than the photochemical production of ozone at this time of year. In fact, the ozone perturbation is negative $(<-1 \mathrm{ppbv})$ over much of the Northern Hemisphere $\left(>40^{\circ} \mathrm{N}\right)$ because of European emissions. In this sense, Europe exports "negative ozone" to the mid and high latitudes during winter. However, northern Africa and the Near East show a modest $(\sim 1$ ppbv) positive perturbation. The changeover from a negative to a positive 


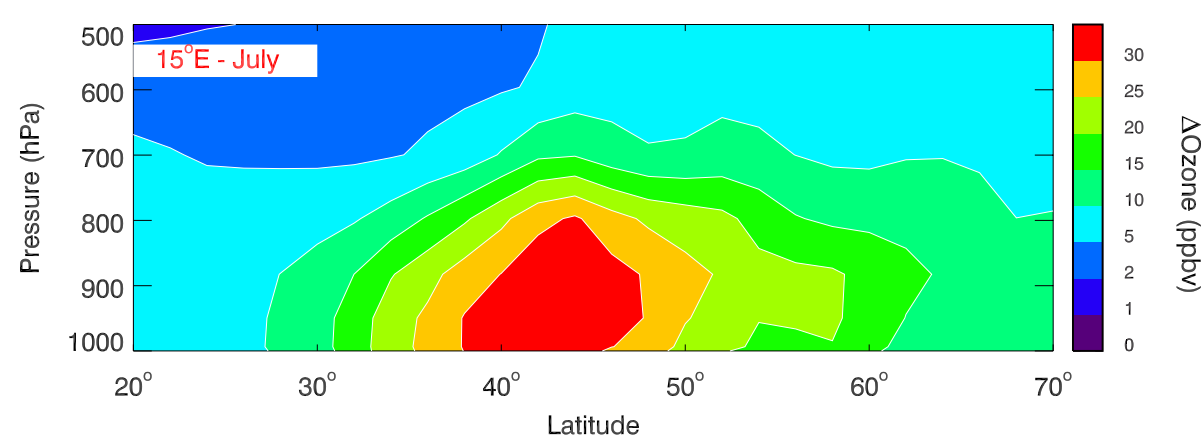

Fig. 5. Vertical cross-section at $15^{\circ} \mathrm{E}$ of the difference in model ozone (ppbv) in July between RUN1 and RUN2.

a)
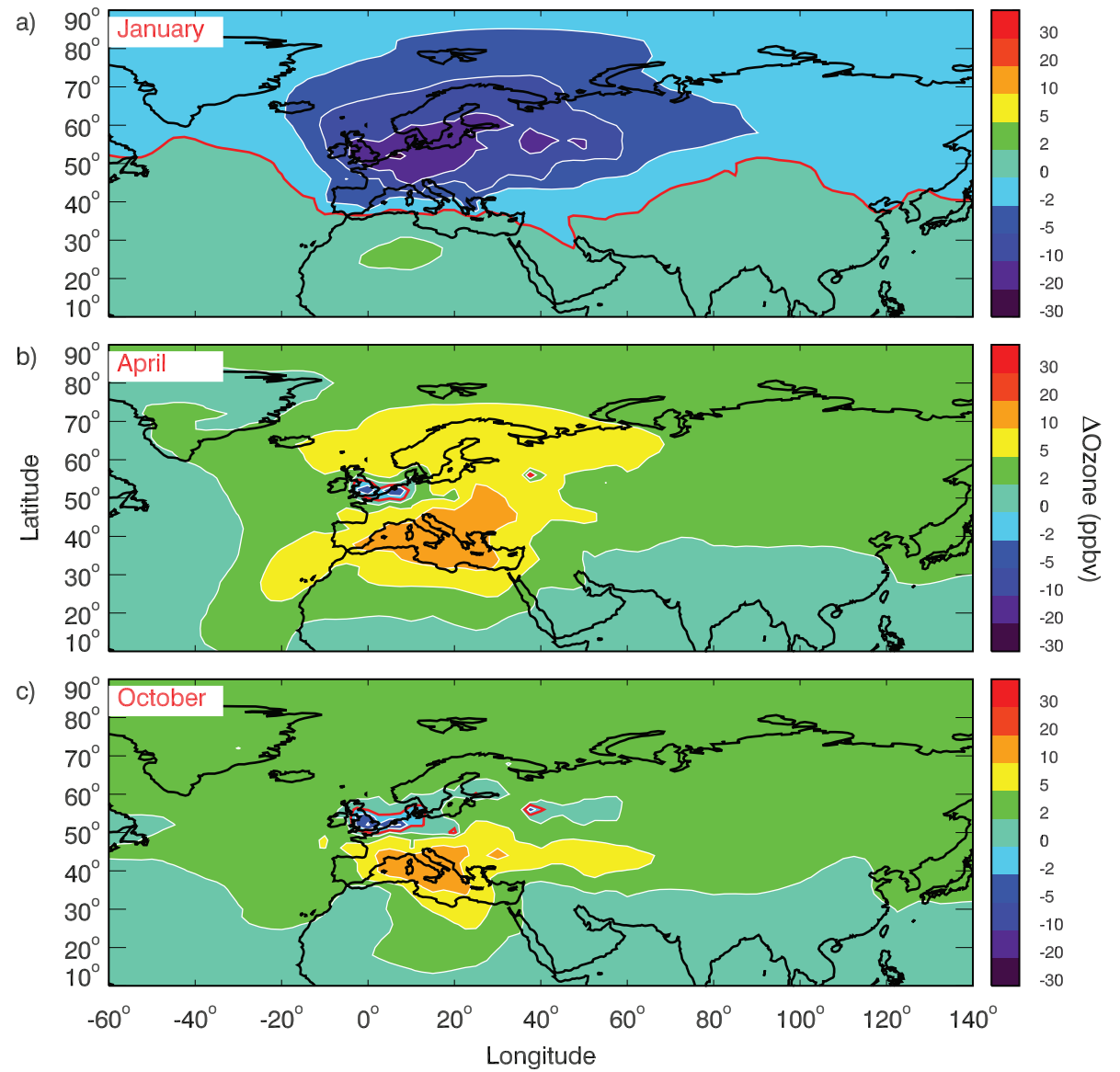

Fig. 6. Same as Fig. 4c, except for (a) January, (b) April, and (c) October 2001. The zero contour is shown as a red line.

ozone perturbation, the zero perturbation line, is found in the Mediterranean Sea in January (Fig. 6a). The zero perturbation line moves northward into southern Europe through spring and vice-versa in autumn (Fig. 6bc). In these transition times, the perturbation is negative typically over England and the Benelux region, regions with the highest $\mathrm{NO}_{\mathrm{x}}$ emissions.

Additional violations of the European health standard for ozone due to European pollution typically occur from March through October in the Mediterranean Sea region. Figure 7a shows the number of additional violations in July, when there are at least 10 additional violations over Egypt, including the heavily populated Nile River valley, much of the northern African and eastern Mediterranean coasts, including Israel, Jordan and Turkey. In fact, for many heavily populated regions, additional violations occur almost every day in June, July, and August. For the entire year (Fig. 7b), the number of additional violations ranges from $50-150$ in these same 

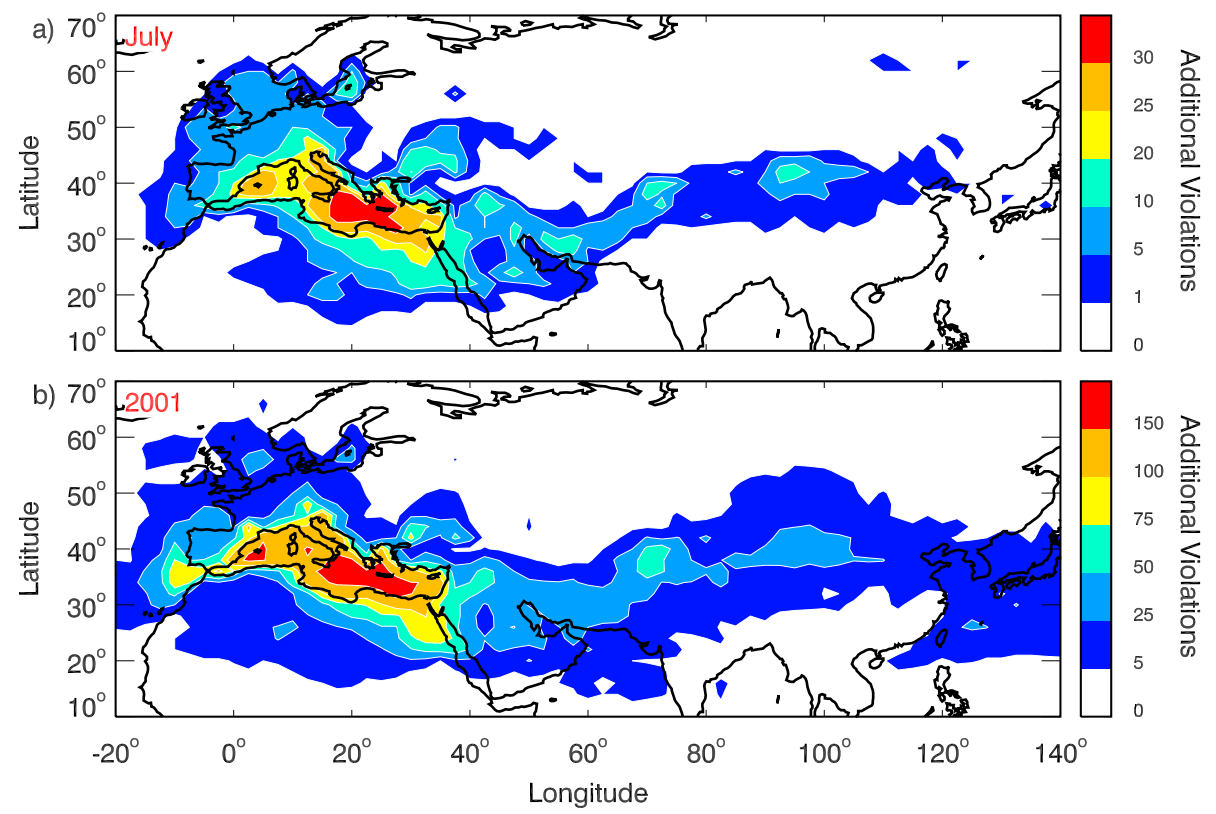

Fig. 7. Number of additional violations of the European health standard for ozone in (a) July and (b) over the entire year, resulting from European pollution in 2001 .

regions. As shown in the figure, additional violations are found in much of the Middle East as well, including the Arabian peninsula, Iraq, Iran, Pakistan, and even as far downwind as China.

Our estimate of the number of additional violations may be high as our model surface ozone tends to be biased high in Europe in summer as discussed above; however there are few, if any, observations of surface ozone in northern Africa and the Near East with which to evaluate our model bias in these regions.

\section{Impact of European emissions on human mortality}

In this section, we estimate the impacts of ozone associated with European emissions, presented above, on premature human mortality. We follow the methods of West et al. (2006) in estimating the number of premature mortalities in the Northern Hemisphere, due to ozone from European emissions. We do not estimate the effects of changes in particulate matter concentrations on mortality, but note that particulate matter has been strongly related with mortality (Pope et al., 2002). An assessment of the total burden of European air pollutant emissions on premature human mortality would need to also include particulate matter. We also acknowledge the potential for European emissions to impact quality of life (e.g. from increased illness) and the economy (e.g. from an increased number of sick days of employees or reduced crop yield) though we do not estimate these impacts here.
The equation for the change in human mortalities ( $\Delta$ Mort) due to a change in ozone concentration $\left(\Delta \mathrm{O}_{3}\right)$ used in the epidemiological studies and in this study is:

$\Delta$ Mort $=-y_{0}\left(e^{-\beta \Delta O_{3}}-1\right)$ Pop

where $y_{0}$ is the baseline mortality rate for a given population, $\beta$ is the mortality coefficient determined by the epidemiological studies (the fraction of additional mortalities per ppbv of ozone), and Pop is the total population. We use the $\beta$ for 8-h daily maximum ozone determined by Bell et al. (2004), who use a large database of 95 cities in the United States and a distributed lag method. We select this $\beta$ because it is not subject to the publication bias that may affect metaanalyses of the existing literature; using the $\beta$ from recent meta-analyses (Bell et al., 2005; Ito et al., 2005; Levy et al., 2005 ) would give $\sim 30 \%$ more mortalities. While this value of $\beta$ was determined in the United States, similar results have been found in Europe (Gryparis et al., 2004) and in some of the relatively fewer studies conducted in less industrialized nations (Borja-Aburto et al., 1998; Kim et al., 2004; O’Neill et al., 2004).

The distribution of population is taken from the LandScan database (Oak Ridge, 2005) for the 2003 population, which is then mapped onto the grid used for atmospheric modeling. Values of $y_{0}$ are derived from the World Health Organization (2004) for the total non-accident baseline mortality in each of fourteen world regions, where these regions are defined by the World Health Organization (2004) and mapped onto the modeling grid as in West et al. (2006). Changes in mortality are calculated on each day and in each model grid cell using 


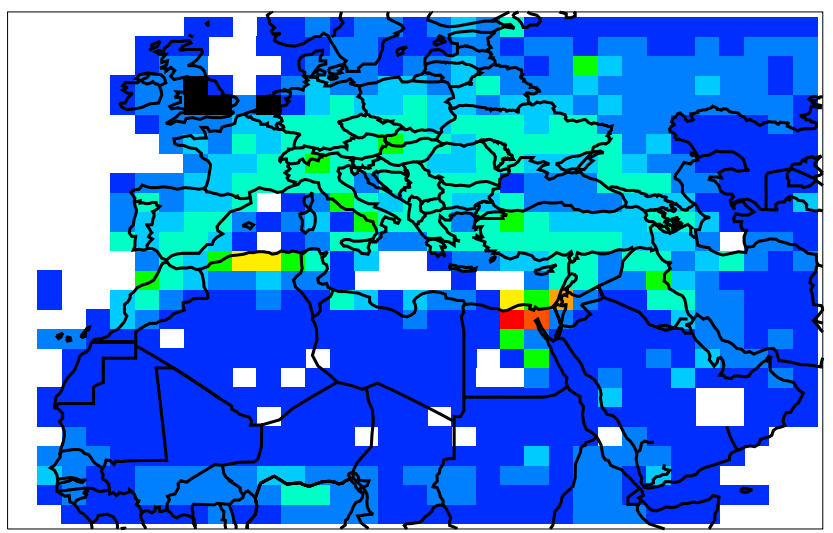

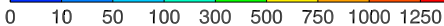

Fig. 8. Premature mortalities (per year) due to emission reductions in Europe. Black boxes represent regions with increased premature mortalities (i.e. fewer mortalities in the simulation with European pollution than without it).

the change in 8-h ozone concentration between RUN1 and RUN2, using the appropriate population and $y_{0}$ for each cell. We assume a low-concentration threshold of $25 \mathrm{ppbv}$, below which changes in ozone are assumed to have no effect on human mortality.

Table 2 shows the changes in population-weighted annual average 8 -h daily maximum ozone concentrations and in premature mortality in several regions of the Northern Hemisphere. Here we see that when removing European emissions, the population-weighted ozone decrease is actually greater in the Near East than in Europe itself, with substantial decreases also in the Former Soviet Union and northern Africa (considering the portion of Africa in the Northern Hemisphere), in agreement with Figs. 4 and 6. Note that the European region extends to $60^{\circ} \mathrm{E}$, which includes about $68 \%$ of the population of the Former Soviet Union. Therefore, RUN2 includes reductions in emissions for most of the industrialized regions of the Former Soviet Union, including all of Belarus and Ukraine and parts of Russia and Kazakhstan.

The premature ozone-related mortalities resulting from European emissions are shown in Fig. 8. This distribution of mortalities is the result of the spatial distribution of the change in ozone, the population distribution, and the baseline mortality rates in different regions. The figure shows that the greatest density of premature mortalities occurs in regions along the Mediterranean with the greatest population density, in particular, in Egypt, Israel, Lebanon, Jordan, and Algeria. Parts of these regions have a greater density of population than in Mediterranean Europe. Algeria also has a greater baseline mortality rate than Western Europe, while Egypt, Jordan, Israel and Lebanon have baseline mortality rates roughly equal to or less than those in Western Europe.

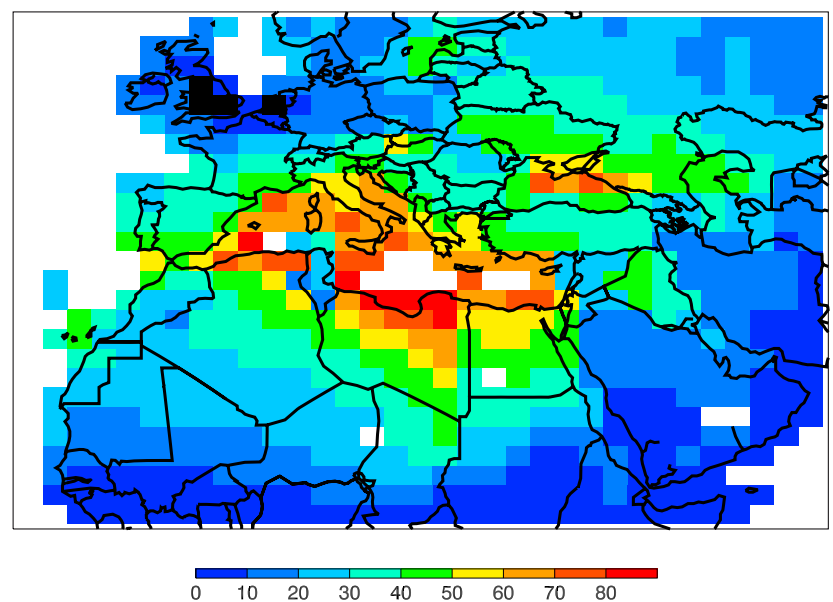

Fig. 9. Premature mortalities per million people (per year) in the population of each grid cell. Black boxes represent regions with increased premature mortalities (i.e. fewer mortalities in the simulation with European pollution than without it).

We estimate that the total burden of European emissions on ozone-related mortality in the Northern Hemisphere is about 51000 premature mortalities per year (Table 2). Of these, roughly $37 \%$ percent occur in the European source region itself, with the majority of the premature mortalities outside of this source region. This finding that European emissions actually cause more ozone-related mortalities outside of the source region is consistent with other recent findings using another global CTM (West et al., 2008 $\mathrm{a}^{1}$ ), and will be discussed further below. Roughly $21 \%$ of the mortalities are in Africa, and $16 \%$ are in the Near East. Interestingly, there are also fairly large numbers of premature mortalities in South Asia, East Asia, and even in North America; while the change in ozone concentration is small in these regions, the numbers of people exposed are large. We find that European emissions decrease mortalities in some regions of England and Benelux, due to the increased titration of ozone by reaction with fresh $\mathrm{NO}$ emissions.

Figure 9 shows that the greatest number of premature mortalities per million people in the population occurs in the regions bordering the Mediterranean Sea, where the change in ozone is the greatest. Among the regions in Table 2, the premature mortalities per million people are greatest in Europe. In Fig. 9, some discontinuities are seen at national boundaries; for example, Tunisia is markedly lower than the bordering Algeria. This occurs because the WHO (2004) defines baseline mortality rates in world regions, and Tunisia is in a WHO region that has a much lower baseline mortality rate than Algeria.

\footnotetext{
${ }^{1}$ West, J. J., Naik, V., Horowitz, L. W., and Fiore, A. M.: Effect of regional NOx emission controls on long-range ozone transport, in preparation, 2008.
} 
Table 2. Decreases in ozone (the population-weighted annual average 8-h daily maximum) when European emissions are removed, including premature mortalities per year, in each of eight Northern Hemisphere regions.

\begin{tabular}{lcccc}
\hline Region $^{\mathrm{a}}$ & $\begin{array}{c}\text { Pop. } \\
\text { (millions) }\end{array}$ & $\begin{array}{c}\Delta \mathrm{O}_{3} \\
(\mathrm{ppbv})\end{array}$ & $\begin{array}{c}\text { Premature } \\
\text { mortalities } \\
(/ \mathrm{yr})\end{array}$ & $\begin{array}{c}\text { Premature } \\
\text { mortalities } \\
(/ \text { million/yr })\end{array}$ \\
\hline Europe & 688.9 & 6.0 & 18,800 & 27.3 \\
Northern Africa & 626.4 & 4.1 & 10700 & 17.1 \\
Near/Middle East $^{\mathrm{b}}$ & 408.6 & 7.0 & 8400 & 20.5 \\
Former Soviet Union $^{\mathrm{c}}$ & 98.7 & 4.5 & 1700 & 17.7 \\
South Asia $^{\mathrm{d}}$ & 1267.1 & 0.8 & 3800 & 3.0 \\
East Asia $^{\mathrm{e}}$ & 1518.5 & 1.4 & 5800 & 3.8 \\
Southeast Asia $^{\mathrm{f}}$ & 361.9 & 0.4 & 300 & 1.0 \\
America $_{\text {Total Northern Hemisphere }}$ & 578.7 & 0.9 & 1400 & 2.4 \\
\hline
\end{tabular}

${ }^{a}$ Regions are defined in only the Northern Hemisphere.

b Turkey, Cyprus, Israel, Jordan, Syria, Lebanon, countries on the Arabian Peninsula, Iraq, Iran, Afghanistan, and Pakistan.

${ }^{\mathrm{c}}$ East of $60^{\circ} \mathrm{E}$; west of $60^{\circ} \mathrm{E}$ and north of $44^{\circ} \mathrm{N}$ is considered part of the "Europe" region.

d India, Bangladesh, Sri Lanka, Nepal, and Bhutan.

e Japan, Mongolia, China, Taiwan, North Korea, and South Korea.

${ }^{\mathrm{f}}$ Myanmar, Thailand, Laos, Vietnam, Cambodia, Singapore, Philippines, Malaysia, Brunei, and the Northern Hemisphere portion of Indonesia.

The uncertainty in ozone-related mortality calculations is substantial, as the uncertainty in $\beta$ alone causes an uncertainty of a factor of 1.7 in similar estimates of total mortalities, with additional uncertainties due to the ozone modeling, baseline mortality rates, and the low-concentration threshold (West et al., 2006, 2007). Here we are interested in particular in the percentage of total mortalities that occur outside of Europe, for which two sources of uncertainties are particularly important. First, for lack of better information, we apply a $\beta$ determined in United States throughout the Northern Hemisphere. Populations in other world regions may have a different susceptibility to ozone mortality as the general causes of death often differ substantially between regions, and in particular, between the industrialized and developing nations. To attempt to account for these differences in causes of death, we limit the calculation to only cardiovascular and respiratory (CR) mortalities, using the $\beta$ determined by Bell et al. (2004) for CR mortalities and the appropriate baseline mortality rates for CR mortalities. In doing so, we find that European emissions cause about 33500 ozone-related CR mortalities annually, and that the majority of these (57\%) are still outside of the European source region.

Second, some epidemiological studies of ozone-related mortality, all in temperate regions, have found different results in summer than in winter (Gryparis et al., 2004; Ito et al., 2005; Levy et al., 2005), while other studies have found no significant difference between seasons (Bell et al., 2004). Since other regions affected by European emissions do not experience the same seasonal difference in ozone as the United States and Europe, we used a low-concentration threshold of $25 \mathrm{ppbv}$ in the above results, rather than distinguishing between seasons. We test the sensitivity of our results to this approach first by increasing the lowconcentration threshold, which will exclude more winter days in Europe. Raising the threshold to $40 \mathrm{ppbv}$ gives 37700 premature all-cause mortalities in the Northern Hemisphere, with $66 \%$ of these mortalities outside of Europe. Second, we exclude the winter months, focusing on the period of April through October and using a 25 ppbv threshold. Doing so, we find that that European emissions cause 44800 premature mortalities in the Northern Hemisphere, with a slight majority (51\%) of these mortalities in Europe itself. If ozone truly does not affect mortality in the winter in Europe, this last estimate would be more accurate for impacts in Europe, but may underestimate European impacts elsewhere in the Northern Hemisphere, where ozone does not follow the same seasonal pattern.

\section{Conclusions}

In this study, we used the GMI CTM to assess the impact of European pollution on surface ozone in 2001. The ability of the model to reproduce observations reasonably well, despite its limitations discussed in Sect. 3.1, lends confidence in its use as a tool to study the impact of European pollution on air quality in northern Africa and the Near East.

We show that European pollution regularly and significantly elevates surface ozone above the European health standard (i.e. 8 -h average of $120 \mu \mathrm{g} / \mathrm{m}^{3}$ or $\sim 60 \mathrm{ppbv}$ ) in northern Africa and the Near East, especially in summer 
when prevailing winds favor transport from Europe to these photochemically productive regions. In July, European pollution elevates average surface ozone in northern Africa by 10-20 ppbv and by 5-10 ppbv in the Near East. For perspective, European pollution elevates surface ozone by typically 10-30 ppbv over southern Europe and 10-20 ppbv over northern Europe.

We estimate that European pollution causes 20-30 and 1025 additional violations of the European health standard in July in northern Africa and the Near East, respectively. That is, more than half of the days in July exceed the health standard because of the long-range transport of European pollution. High levels of ozone, above the threshold for the health standard and 2.5-3 times higher than background, were measured in the boundary layer over the Mediterranean Sea in summer 2001 during the MINOS field campaign and attributed to European pollution (Lelieveld et al., 2002). Annually, there are between 50 and 150 additional violations of the health standard in northern Africa and the Near East because of European pollution. European emissions elevate ozone throughout most of the year in these regions (e.g. by 2$10 \mathrm{ppbv}$ in October), though minimally in winter. In fact, European emissions actually decrease ozone over most of Europe and latitudes higher than $40^{\circ} \mathrm{N}$ in winter, due to titration of ozone by NO and low photochemical production of ozone. However, this is not necessarily beneficial for human health as ozone concentrations are low in winter; that is, almost no violations of the health standard occur at latitudes greater than $40^{\circ} \mathrm{N}$ in winter.

While the contribution of European pollution to ozone in northern Africa and the Near East is high (Fig. 4c), it becomes even more important when one considers that the ozone in these regions in our simulation without European pollution (i.e. RUN2) is closer to the health standard than in Europe itself (Fig. 4b); this occurs as the photochemical environment in northern Africa and the Near East is more conducive (e.g. ample sunlight) to ozone production as compared to the typical environment in Europe. Consequently, the exported European pollution has a large impact on surface ozone in northern Africa and the Near East, especially since the long-range transport of ozone and its precursors from Europe occurs near the surface. Even pollution that is vented to the free troposphere during summer over the Alps has been shown to descend over the Mediterranean Sea (Henne et al., 2005).

We show that European pollution has a significant impact on human health outside of Europe's borders despite the uncertainty associated with this estimate of additional deaths (e.g. the limited understanding of the effect of ozone on mortality outside the United States and Europe) and the limitations of the model simulation as discussed in Sect. 3.1. We estimate that 50000 additional deaths occur annually due to ozone produced from European pollution, with 19000 of those deaths occurring in northern Africa and the Near East and the majority of deaths attributed to European ozone oc- curring outside of Europe. About 9500 additional deaths also occur far downwind in South and East Asia; while the contribution from European ozone is small ( $<5 \mathrm{ppbv}$ in July), large populations are exposed. While we focused on the year 2001, European pollution likely impacts air quality in northern Africa and the Near East in other years as well, as southward flow from Europe at low altitudes typically occurs each year, especially in summer (Duncan and Bey, 2004).

Our results indicate that pollution control strategies within European countries, implemented to minimize local violations of the health standard for ozone, would also help to abate ozone pollution in countries in northern Africa and the Near East, with benefits for public health in these regions. The Task Force on Hemispheric Transport of Air Pollution (www.htap.org/) recently sponsored a CTM study to better understand the impact of the long-range transport of pollution on air quality in four major industrialized regions (i.e. Europe, East Asia, South Asia, and North America), but not northern Africa and the Near East. Our results show that air quality in northern Africa and the Near East would benefit from an international approach to managing air quality.

Acknowledgements. We would like to thank the GMI science team for their efforts which has facilitated our research. The emissions database used in this work was developed by J. A. Logan, R. C. Hudman, Y. X. Wang, and R. M. Yantosca for the GEOS-Chem model at Harvard University. This research was supported by NASA Grant MAP/04-0068-0040.

Edited by: N. Mihalopoulos

\section{References}

Anderson, H. R., Atkinson, R. W., Peacock, J. L., Marston, L., and Konstantinou, K.: Meta-analysis of time-series studies and panel studies of particulate matter $(\mathrm{PM})$ and ozone $\left(\mathrm{O}_{3}\right)$, World Health Organization, Geneva, 2004.

Auvray, M. and Bey, I.: Long-range transport to Europe: Seasonal variations and implications for the European ozone budget, J. Geophys. Res., 110, D11303, doi:10.1029/2004JD005503, 2005.

Bell, M. L., McDermott, A., Zeger, S. L., Samet, J. M., and Dominici, F.: Ozone and short-term mortality in 95 US urban communities, 1987-2000, JAMA, 292(19), 2372-2378, 2004.

Bell, M. L., Dominici, F., and Samet, J. M.: A meta-analysis of time-series studies of ozone and mortality with comparison to the National Morbidity, Mortality, and Air Pollution Study, Epidemiology, 16(4), 436-445, 2005.

Bell, M. L., Peng, R. D., and Dominici, F.: The exposure-response curve for ozone and risk of mortality and the adequacy of current ozone regulations, Environ. Health Perspect., 114(4), 532-536, 2006.

Berntsen, T. K., Karlsdottir, S., and Jaffe, D. A.: Influence of Asian emissions on the composition of air reaching the North Western United States, Geophys. Res. Lett., 26, 2171-2174, 1999.

Bhartia, P. K., McPeters, R. D., Mateer, C. L., Flynn, L. E., and Wellemeyer, C.: Algorithm for the estimation of vertical ozone 
profiles from the backscattered ultraviolet technique, J. Geophys. Res., 101, 18 793-18 806, 1996.

Bloom, S., da Silva, A., Dee, D., Bosilovich, M., Chern, J.-D., Pawson, S., Schubert, S., Sienkiewicz, M., Stajner, I., Tan, W.-W., and $\mathrm{Wu}$, M.-L.: Documentation and validation of the Goddard Earth Observing System (GEOS) Data Assimilation System Version 4, Technical Report Series on Global Modeling and Data Assimilation 104606, 2004.

Borja-Aburto, V. H., Castillejos, M., Gold, D. R., Bierzwinski, S., and Loomis, D.: Mortality and ambient fine particles in southwest Mexico City, 1993-1995, Environ. Health Perspect., 106(12), 849-855, 1998.

Challen, P. D., Hickish, D., and Bedford, J.: An investigation of some health hazards in an inert-gas tungsten-arc welding shop, Br. J. Ind. Med., 15, 276-282, 1958.

Chameides, W. L., Fehsenfeld, F., Rodgers, M. O., et al.: Ozone precursor relationships in the ambient atmosphere, J. Geophys. Res., 97, 6037-6055, 1992.

Chen, G., Huey, L. G., Trainer, M., et al.: An investigation of the chemistry of ship emission plumes during ITCT 2002, J. Geophys. Res., 110, D10S90, doi:10.1029/2004JD005236, 2005.

Chevalier, A., Gheusi, F., Delmas, R., et al.: Influence of altitude on ozone levels and variability in the lower troposphere: a groundbased study for western Europe over the period 2001-2004, Atmos. Chem. Phys., 7, 4311-4326, 2007,

http://www.atmos-chem-phys.net/7/4311/2007/.

Chin, M., Ginoux, P., Kinne, S., Torres, O., Holben, B., Duncan, B., Martin, R., Logan, J., Higurashi, A., and Nakajima. T.: Tropospheric aerosol optical thickness from the GOCART model and comparisons with satellite and sunphotometer measurements, J. Atmos. Sci., 59, 461-483, 2002.

Collins, W. J., Stevenson, D. S., Johnson, C. E., and Derwent, R. G.: The European regional ozone distribution and its links with the global scale for the years 1992 and 2015, Atmos. Environ., 34, 255-267, 2000.

Davis, D. D., Grodzinsky, G., Kasibhatla, P., et al.: Impact of ship emissions on marine boundary layer $\mathrm{NO}_{\mathrm{x}}$ and $\mathrm{SO}_{2}$ distributions over the Pacific basin, Geophys. Res. Lett., 28, 235-238, 2001.

de Laat, A. T. J., Aben, I., and Roelofs, G. J.: A model perspective on total tropospheric $\mathrm{O}_{3}$ column variability and implications for satellite observations, J. Geophys. Res., 110, D13303, doi:10.1029/2004JD005264, 2005.

Duncan, B. N. and Bey, I.: A Modeling Study of the Export Pathways of Pollution from Europe: Seasonal and Interannual Variations (1987-1997), J. Geophys. Res., 109, D08301, doi:10.1029/2003JD004079, 2004.

Duncan, B. N., Strahan, S. E., and Yoshida, Y.: Model study of the cross-tropopause transport of biomass burning pollution, Atmos. Chem. Phys., 7, 3713-3736, 2007,

http://www.atmos-chem-phys.net/7/3713/2007/.

Eyring, V., Stevenson, D. S., Lauer, A., Dentener, F. J., et al.: Multi-model simulations of the impact of international shipping on atmospheric chemistry and climate in 2000 and 2030, Atmos. Chem. Phys., 7, 757-780, 2007, http://www.atmos-chem-phys.net/7/757/2007/.

Fiore, A. M., Jacob, D. J., Field, B. D., Streets, D. G., Fernandes, S. D., and Jang, C.: Linking ozone pollution and climate change: The case for controlling methane, Geophys. Res. Lett., 29(19), 1919, doi:10.1029/2002GL015601, 2002a.
Fiore, A. M., Jacob, D. J., Mathur, R., and Martin, R. V.: Application of empirical orthogonal functions to evaluate ozone simulations with regional and global models, J. Geophys. Res., 108, 4431, doi:10.1029/2002JD003151, 2003.

Fiore, A. M., Horowitz, L. W., Purves, D. W., Levy II, H., et al.: Evaluating the contribution of changes in isoprene emissions to surface ozone trends over the eastern United States, J. Geophys. Res., 110, D12303, doi:10.1029/2004JD005485, 2005.

Guenther, A., Hewitt, C. N., Erickson, D., Fall, R., et al.: A global model of natural volatile organic compound emissions, J. Geophys. Res., 100, 8873-8892, 2005.

Gryparis, A., Forsberg, B., Katsouyanni, K., et al.: Acute effects of ozone on mortality from the "Air pollution and health: A European approach" project, Am. J. Respir. Crit. Care Med., 170(10), 1080-1087, 2004.

Guenther, A., Karl, T., Harley, P., Wiedinmyer, C., Palmer, P. I., and Geron, C.: Estimates of global terrestrial isoprene emissions using MEGAN (Model of Emissions of Gases and Aerosols from Nature), Atmos. Chem. Phys., 6, 3181-3210, 2006, http://www.atmos-chem-phys.net/6/3181/2006/.

Henne, S., Dommen, J., Neininger, B., Reimann, S., Staehelin, J., and Prévôt, A. S. H.: Influence of mountain venting in the Alps on the ozone chemistry of the lower free troposphere and the European pollution export, J. Geophys. Res., 110, D22307, doi:10.1029/2005JD005936, 2005.

Hallet, W.: Effect of ozone and cigarette smoke on lung function, Arch. Environ. Health, 10, 295-302, 1965.

Ito, K., De Leon, S. F., and Lippman, M.: Associations between ozone and daily mortality, Epidemiology, 16(4), 446-457, 2005.

Jacob, D. J., Logan, J. A., Yevich, R. M., et al.: Simulation of summertime ozone over North America, J. Geophys. Res., 98, 14 797-14 816, 1993a.

Jacob, D. J., Logan, J. A., Gardner, G. M., et al.: Factors regulating ozone over the United Sates and its export to the global atmosphere, J. Geophys. Res., 98, 14 817-14 826, 1993 b.

Jacob, D. J., Logan, J. A., and Murti, P. P.: Effect of rising Asian emissions on surface ozone in the United States, Geophys. Res. Lett., 26, 2175-2178, 1999.

Jacobson, M. Z.: Computation of global photochemistry with SMVGEAR II, Atmos. Environ., 29, 2541-2546, 1995.

Jaffe, D., Anderson, T., Covert, D., et al.: Transport of Asian air pollution to North America, Geophys. Res. Lett., 26(6), 711714, 1999.

Kallos, G., Kotroni, V., Lagouvardos, K., and Papadopoulos, A.: On the long-range transport of air pollutants from Europe to Africa, Geophys. Res. Lett., 25(5), 619-622, 1998.

Kallos, G., Astitha, M., Katsafados, P., and Spyrou, C.: Long-range transport of anthropogenically and naturally produced particulate matter in the Mediterranean and North Atlantic: Current state of knowledge, J. Appl. Meteorol., 46(8), 1230-1251, 2007.

Kasibhatla, P., Levy II, H., Moxim, W. J., et al.: Do emissions from ships have a significant impact on concentrations of nitrogen oxides in the marine boundary layer?, Geophys. Res. Lett., 27, 2229-2232, 2000.

Kim, S. Y., JongTae, L., Lee, J. T., et al.: Determining the threshold effect of ozone on daily mortality: an analysis of ozone and mortality in Seoul, Korea, 1995-1999, Environ. Res., 94(2), 113 119,2004

Kleinfield, M., Giel, C., and Tabershaw, I.: Health hazards associ- 
ated with inert gas shield metal arc welding, Arch. Ind. Health, 15, 27-31, 1957.

Kuhns, H., Green, M., and Etyemezian, V.: Big Bend Regional Aerosol and Visibility Observational (BRAVO) Study Emissions Inventory, Desert Research Institute Report, 2003.

Lelieveld, J., Berresheim, H., Borrmann, S., et al.: Global air pollution crossroads over the Mediterranean, Science, 298, 794-799, 2002.

Levy, J. I., Carrothers, T. J., Tuomisto, J. T., Hammitt, J., and Evans, J. S.: Assessing the public health benefits of reduced ozone concentrations, Environ. Health Perspect., 109(12), 1215-1226, 2001.

Levy, J. I., Chemerynski, S. M., and Sarnat, J. A.: Ozone exposure and mortality: an empiric Bayes metaregression analysis, Epidemiology, 16(4), 458-468, 2005.

Li, Q., Jacob, D., Bey, I., et al.: Transatlantic transport of pollution and its effect on surface ozone in Europe and North America, J. Geophys. Res., 107(D13), 4166, doi:10.1029/2001JD001422, 2002.

Liang, J. and Jacobson, M. Z.: Effects of subgrid segregation on ozone production efficiency in a chemical model, Atmos. Environ., 34, 2975-2982, 2000.

Lin, X., Trainer, M., and Liu, S. C.: On the nonlinearity of the tropospheric ozone production, J. Geophys. Res., 93, 15 879-15 888, 1988.

Liu, S. C., Trainer, M., Fehsenfeld, F. C., et al.: Ozone production in the rural troposphere and implications for regional and global ozone distributions, J. Geophys. Res., 92, 4194-4207, 1987.

Liu, H., Jacob, D. J., Bey, I., and Yantosca, R. M.: Constraints from ${ }^{210} \mathrm{~Pb}$ and ${ }^{7} \mathrm{Be}$ on wet deposition and transport in a global threedimensional chemical tracer model driven by assimilated meteorological fields, J. Geophys. Res., 106, 12 109-12 128, 2001.

Martin, R. V., Jacob, D. J., Yantosca, R. M., et al.: Global and regional decreases in tropospheric oxidants from photochemical effects of aerosols, J. Geophys. Res., 108(D3), 4097, doi:10.1029/2002JD002622, 2003.

McClinden, C. A., Olsen, S. C., Hannegan, B., Wild, O., Prather, M. J., and Sundet, J.: Stratospheric ozone in 3-D models: A simple chemistry and the cross-tropopause flux, J. Geophys. Res., 105, 14 653-14 665, 2000.

Monks, P. S.: A review of the observations and origins of the spring ozone maximum, Atmos. Environ., 34, 3545-3561, 2000.

Murazaki, K. and Hess, P.: How does climate change contribute to surface ozone change over the United States?, J. Geophys. Res., 111, D05301, doi:10.1029/2005JD005873, 2006.

Oak Ridge National Laboratory, Land Scan 2003, edited, 2005.

Olivier, J. G. J., Berdowski, J. J. M., Peters, J. A. H. W., Bakker, J., Visschedijk, A. J. H., and Bloos, J.-P. J.: Applications of EDGAR. Including a description of EDGAR 3.0: reference database with trend data for 1970-1995. RIVM, Bilthoven. RIVM report no. 773301 001/ NOP report no. 410200 051, 2001.

Olsen, S. C., McLinden, C. A., and Prather, M. J.: Stratospheric $\mathrm{N}_{2} \mathrm{O}-\mathrm{NO}_{\mathrm{y}}$ system: Testing uncertainties in a three-dimensional framework, J. Geophys. Res., 106, 28 771-28 784, 2001.

O'Neill, M. S., Loomis, D., and Borja-Aburto, V. H.: Ozone, area social conditions, and mortality in Mexico City, Environ. Res., 94(3), 234-242, 2004.

Park, R. J., Pickering, K. E., Allen, D. J., Stenchikov, G. L., FoxRabinovitz, M. S.: Global simulation of tropospheric ozone using the University of Maryland Chemical Transport Model (UMD-CTM): 2. Regional transport and chemistry over the central United States using a stretched grid, J. Geosphys. Res., 109, D09303, doi:10.1029/2003JD004269, 2004.

Piccot, S., Watson, J., and Jones, J.: A global inventory of volatile organic compound emissions from anthropogenic sources, J. Geophys. Res., 97, 9897-9912, 1992.

Pope, C. A., Burnett, R. T., Thun, M. J., et al.: Lung cancer, cardiopulmonary mortality, and long-term exposure to fine particulate air pollution, J. Am. Med. Assoc., 287(9), 1132-1141, 2002.

Prather, M., Gauss, M., Berntsen, T., et al.: Fresh air in the 21st century?, Geophys. Res. Lett., 30, 1100, doi:10.1029/2002GL016285, 2003.

Reiter, R., Sladkovic, R., and Kanter, H.-J.: Concentration of trace gases in the lower troposphere, simultaneously recorded at neighboring mountain stations, Meteorol. Atmos. Phys., 37, 27-47, 1987.

Roelofs, G. J., Scheeren, H. A., Heland, J., Ziereis, H., and Lelieveld, J.: A model study of ozone in the eastern Mediterranean free troposphere during MINOS (August 2001), Atmos. Chem. Phys., 3, 1199-1210, 2003,

http://www.atmos-chem-phys.net/3/1199/2003/.

Sander, S. P., Friedl, R. R., Ravishankara, A. R., et al.: Chemical Kinetic and Photochemical Data for Use in Atmospheric Studies, Evaluation Number 15, NASA Jet Propulsion Laboratory, JPL Publication 06-2, 2006.

Schoeberl, M. R., Duncan, B. N., Douglass, A. R., Waters, J., Livesey, N., Read, W., and Filipiak, M.: The carbon monoxide tape recorder, Geophys. Res. Lett., 33, L12811, doi:10.1029/2006GL026178, 2006.

Sillman, S., Logan, J. A., and Wofsy, S. C.: A regional scale model for ozone in the United States with subgrid representation of urban and power plant plumes, J. Geophys. Res., 95, 5731-5748, 1990.

Song, C. H., Chen, G., Hanna, S. R., Crawford, J., and Davis, D. D.: Dispersion and chemical evolution of ship plumes in the marine boundary layer: Investigation of $\mathrm{O}_{3} / \mathrm{NO}_{\mathrm{y}} / \mathrm{HO}_{\mathrm{x}}$ chemistry, $\mathrm{J}$. Geophys. Res., 108, 4143, doi:10.1029/2002JD002216, 2003.

Stockinger, H.: Ozone toxicology: A review of research and industrial experience, Arch. Environ. Health, 10, 719-731, 1965.

Stohl, A., Eckhardt, S., Forster, C., James, P., and Spichtinger, N.: On the pathways and timescales of intercontinental air pollution transport, J. Geophys. Res., 107, 4684, doi:10.1029/2001JD001396, 2002.

Stohl, A., Forster, C., Eckhardt, S., Spichtinger, N., Huntrieser, H., Heland, J., Schlager, H., Wilhelm, S., Arnold, F., and Cooper, O.: A backward modeling study of intercontinental pollution transport using aircraft measurements, J. Geophys. Res., 108, 4370, doi:10.1029/2002JD002862, 2003.

Strahan, S. E., Duncan, B. N., and Hoor, P.: Observationally derived transport diagnostics for the lowermost stratosphere and their application to the GMI chemistry and transport model, Atmos. Chem. Phys., 7, 2435-2445, 2007, http://www.atmos-chem-phys.net/7/2435/2007/.

Streets, D. G., Bond, T. C., Carmichael, G. R., et al.: An inventory of gaseous and primary aerosol emissions in Asia in the year 2000, J. Geophys. Res., 108, 8809, doi:10.1029/2002JD003093, 2003.

Streets, D. G., Zhang, Q., Wang, L., He, K., Hao, J., Wu, Y., 
Tang, Y., and Carmichael G. R.: Revisiting China's CO emissions after TRACE-P: Synthesis of inventories, atmospheric modeling, and observations, J. Geophys. Res., 111, D14306, doi:10.1029/2006JD007118, 2006.

Thurston, G. D. and Ito, K.: Epidemiological studies of acute ozone exposures and mortality, J. Expo. Anal. Environ. Epidemiol., 11(4), 286-294, 2001.

Traub, M., Fischer, H., de Reus, M., et al.: Chemical characteristics assigned to trajectory clusters during the MINOS campaign, Atmos. Chem. Phys., 3, 459-468, 2003, http://www.atmos-chem-phys.net/3/459/2003/.

Trickl, T., Cooper, O. R., Eisele, H., James, P., Mücke, R., and Stohl, A.: Intercontinental transport and its influences on the ozone concentrations over central Europe: Three case studies, J. Geophys. Res., 108(D12), 8530, doi:10.1029/2002JD002735, 2003.

Vestreng, V., Breivik, K., Adams, M., et al.: Inventory Review 2005, Emission Data reported to LRTAP Convention and NEC Directive, Initial review of HMs and POPs, Technical report MSC-W 1/2005, ISSN 0804-2446, 2005.

von Glasow, R., Lawrence, M. G., Sander, R., and Crutzen, P. J.: Modeling the chemical effects of ship exhaust in the cloud-free marine boundary layer, Atmos. Chem. Phys., 3, 233-250, 2003, http://www.atmos-chem-phys.net/3/233/2003/.

West, J. J., Fiore, A. M., Horowitz, L. W., and Mauzerall, D. L.: Global health benefits of mitigating ozone pollution with methane emission controls, Proc. Natl. Acad. Sci. USA, 103(11), 3988-3993, 2006.
West, J. J., Szopa, S., and Hauglustaine, D. A.: Human mortality effects of future concentrations of tropospheric ozone, Comptes Rendus Geoscience, 339(11-12), 775-783, 2007.

Wild, O., Pochanart, P., and Akimoto, H.: Trans-Eurasian transport of ozone and its precursors, J. Geophys. Res., 109, D11302, doi:10.1029/2003JD004501, 2004.

Wild, O. and Prather, M.: Global tropospheric ozone modeling: Quantifying errors due to grid resolution, J. Geophys. Res., 111, D11305, doi:10.1029/2005JD006605, 2006.

World Health Organization: The World Health Report 2004: Changing History, World Health Organization, Geneva, 2004.

Wunderli, S. and Gehrig, R.: Surface ozone in rural, urban and alpine regions of Switzerland, Atmos. Environ. Part A, 24, 26412646, 1990.

Young, W., Shaw, D., and Bates., D.: Effects of low concentrations of ozone on pulmonary function in man, J. Appl. Physiol., 19, 765-768, 1964.

Ziemke, J. R., Chandra, S., Duncan, B. N., Froidevaux, L., Bhartia, P. K., Levelt, P. F., and Waters, J. W.: Tropospheric ozone determined from Aura OMI and MLS: Evaluation of measurements and comparison with the Global Modeling Initiative's Chemical Transport Model, J. Geophys. Res., 111, D19303, doi:10.1029/2006JD007089, 2006. 